\title{
Sensory Neuropathy Attributable to Loss of Bcl-w
}

\author{
Stephanie L. Courchesne, ${ }^{1,2 \star}$ Christoph Karch, ${ }^{1,2 \star}$ Maria F. Pazyra-Murphy, ${ }^{1,2}$ and Rosalind A. Segal ${ }^{1,2}$ \\ ${ }^{1}$ Departments of Cancer Biology and Pediatric Oncology, Dana-Farber Cancer Institute, Boston, Massachusetts 02115, and ${ }^{2}$ Department of Neurobiology, \\ Harvard Medical School, Boston, Massachusetts 02115
}

Small fiber sensory neuropathy is a common disorder in which progressive degeneration of small-diameter nociceptors causes decreased sensitivity to thermal stimuli and painful sensations in the extremities. In the majority of patients, the cause of small fiber sensory neuropathy is unknown, and treatment options are limited. Here, we show that Bcl-w (Bcl-2l2) is required for the viability of small fiber nociceptive sensory neurons. $\mathrm{Bcl}-\mathrm{w}^{-/-}$mice demonstrate an adult-onset progressive decline in thermosensation and a decrease in nociceptor innervation of the epidermis. This denervation occurs without cell body loss, indicating that lack of Bcl-w results in a primary axonopathy. Consistent with this phenotype, we show that Bcl-w, in contrast to the closely related Bcl-2 and Bcl-xL, is enriched in axons of sensory neurons and that Bcl-w prevents the dying back of axons. $\mathrm{Bcl}-\mathrm{w}^{-/-}$sensory neurons exhibit mitochondrial abnormalities, including alterations in axonal mitochondrial size, axonal mitochondrial membrane potential, and cellular ATP levels. Collectively, these data establish $b c l-w^{-/-}$mice as an animal model of small fiber sensory neuropathy and provide new insight regarding the role of Bcl-w and of mitochondria in preventing axonal degeneration.

\section{Introduction}

Small fiber sensory neuropathy is a poorly understood neurodegenerative disorder. Patients exhibit deficits in thermal sensation as well as abnormal painful sensations, or paresthesias (for review, see Stewart et al., 1992; Lacomis, 2002). Multiple causes of small fiber sensory neuropathy have been identified, including diabetes, human immunodeficiency virus infection and/or treatment, and autoimmune disorders (Lacomis, 2002). However, in up to $93 \%$ of patients, the cause is unknown (Periquet et al., 1999). Methods used to diagnose small fiber sensory neuropathy include measuring nerve conduction, sympathetic skin responses, and tests of sudomotor function. However, the most sensitive and reliable diagnostic tools are tests of thermal thresholds and skin biopsy to quantify epidermal nociceptors (Periquet et al., 1999; Lacomis, 2002). Present therapeutics are nonspecific and aimed at relieving pain, not treating the underlying progression of disease. Animal models of small fiber sensory neuropathy

\footnotetext{
Received April 9, 2010; revised 0ct. 20, 2010; accepted Nov. 10, 2010.

This work was supported by National Institutes of Health (NIH) Grant R01 NS050674 (R.A.S.). S.L.C. is a Stuart H. Q. and Victoria Quan Fellow at Harvard Medical School. Confocal microscopy imaging was performed at the Mental Retardation Developmental Disability Research Center Imaging Core, Children's Hospital Boston (NIH Grant P30-HD 18655), and stereology imaging was performed at the Harvard NeuroDiscovery Optical Imaging (enter. We thank Grant MacGregor (University of California, Irvine, Irvine, California) for the generous gift of $b c \mathrm{Cl}^{-/-}$mice. We thank members of Qiufu Ma's laboratory for helpful advice and discussion. We thank Jennifer Kalscheuer, Danny Lee, and Aymeric Hans for assistance, and Katharina Cosker and Sara Fenstermacher for discussion and manuscript suggestions. The research that is the basis of this paper was conducted before S.L.C. started employment at NIH.

*S.L.C. and C.K. contributed equally to this work.

S.L.C., C.K., M.F.P.-M., and R.A.S. contributed to the conception of the study. C.K. and R.A.S. initiated studies on $b c l-w^{-\prime-}$ mice. S.L.C., M.F.P.-M., and R.A.S. designed the experiments and analyzed data. S.L.C. and M.F.P.-M. performed the experiments. S.L.C. and R.A.S. wrote the paper with input from M.F.P.-M.

S. L. Courchesne's present address: Office of the Director, National Institutes of Health, Bethesda, MD 20892.

Correspondence should be addressed to Rosalind Segal, Dana-Farber Cancer Institute, 44 Binney Street, Boston, MA 02115. E-mail: rosalind_segal@dfci.harvard.edu.

DOI:10.1523/JNEUROSCI.3347-10.2011

Copyright $\odot 2011$ the authors $\quad 0270-6474 / 11 / 311624-11 \$ 15.00 / 0$
}

would be useful in delineating the mechanism of this disease, as well as for testing novel, improved therapies.

One major question in the study of neurodegeneration is whether diseases are primarily diseases of cell bodies (neuronopathies) or diseases of axons (axonopathies). These processes are not mutually exclusive, because degeneration of either the cell body or distal axon ultimately leads to dysfunction of the entire cell. However, it is clear that the disease process can begin in a spatially distinct manner. Local insults to axons can elicit degeneration of the neurites without damage to cell bodies (Campenot, 1982; Deckwerth and Johnson, 1994; Sagot et al., 1995, 1996; Burne et al., 1996; Ivins et al., 1998), implying that subcellular compartments can be independently targeted for death. A wide variety of neurodegenerative diseases have been proposed to manifest, at least initially, as axonopathies. These diseases include Alzheimer's disease, motor neuron disease, and sensory neuropathies (for review, see Raff et al., 2002; Vickers et al., 2009).

Recent work from our laboratory has found that the antiapoptotic Bcl-2 family member Bcl-w (Bcl212) is selectively induced in sensory neurons in response to target-derived neurotrophin stimulation, suggesting that $\mathrm{Bcl}-\mathrm{w}$ may be involved in promoting survival of neurons that have been incorporated into a functional circuit (Pazyra-Murphy et al., 2009). Here, we investigate the possibility that $\mathrm{Bcl}-\mathrm{w}$ is involved in sustained survival of sensory neurons into adulthood. We show that mice lacking $\mathrm{Bcl}-\mathrm{w}$ exhibit a progressive decline in detection of noxious thermal stimuli and a coincident degeneration of small fiber innervation in the skin. This degeneration is restricted to the axons, because cell body number is unaffected at symptomatic ages. Bcl-w localizes to mitochondria (O'Reilly et al., 2001), and we find that axonal mitochondria in sensory neurons of $b c l-w^{-1-}$ mice exhibit abnormalities in size and function that may underlie the observed neuropathy. These findings indicate that $b c l-w^{-/-}$ mice provide a model for small fiber sensory neuropathy and 
demonstrate that $\mathrm{Bcl}-\mathrm{w}$ plays a critical role in sustained viability of axonal processes.

\section{Materials and Methods}

Animal use. Timed pregnant rats and adult rats were purchased from Charles River. $b c l-w^{-1-}$ mice were a generous gift from Grant MacGregor (University of California, Irvine, Irvine, CA) (Ross et al., 1998). Genotyping for the wild-type $b c l$ - $w$ gene and/or lac $Z$ gene were performed by Transnetyx using the Bcl-w targeting sequence GCTCTGAACCTCCCCATGACTTAAATCCGTTGCTCTTTCTTGGCCCTGCCCAGTGCCTCTGAGCATTTCACCTATCTCAGGAGC and the lacZ targeting sequence CGATCGTAATCACCCGAGTGTGATCATCTGGTCGCTGGGGAATGAGTCAGGCCACGG or by PCR amplification of DNA from tail samples using the following primers: $5^{\prime}$-ctc ccc atg act taa atc cgt tgc tc- $3^{\prime} ; 5^{\prime}$-agt ttg tcc tca acc gcg agc tgt gg- $3^{\prime}$; and $5^{\prime}-\mathrm{ttt} \mathrm{ccc}$ atg aag acc aac ttt gta ga- $3^{\prime}$. All experimental procedures were done in accordance with the National Institutes of Health guidelines and were approved by the Dana-Farber Cancer Institutional Animal Care and Use Committee.

Behavioral testing. Thermosensation and mechanosensation testing was performed as described previously (Chen et al., 2006). All animals were acclimated to the testing apparatus on at least two habituation sessions. To measure noxious mechanosensation, animals were placed on an elevated wire grid, and the lateral plantar surface of the right hindpaw was simulated with von Frey monofilaments (0.041-1.42 g). Withdrawal threshold for the von Frey assay was determined to be the applied force at which the animal withdrew the paw on at least 2 of 10 applications. To measure noxious thermosensation, mice were placed on a hotplate (Ugo Basile), and the latency to hindpaw withdrawal at $50.0^{\circ} \mathrm{C}$ was measured. Two measurements on consecutive days were averaged for each animal. Significance was calculated by Student's two-tailed $t$ test and two-way ANOVA.

Grip strength was measured using a digital grip strength meter, which records the maximal strength an animal exerts while trying to resist an opposing pulling force (Columbus Instruments). Forelimb grip strength was measured using a mouse tension bar, and hindlimb grip strength was measured using a mouse compression bar. The results of three consecutive trials on the same day were averaged for each animal. Significance was calculated by Student's two-tailed $t$ test at every third time point ( 3 month, 6 month, etc.). For all behavioral experiments, testers were blind to genotype.

Epidermal innervation. Animals were killed with isoflurane, and then footpad tissue from hindpaws was removed, fixed overnight in Zamboni's fixative at $4.0^{\circ} \mathrm{C}$, and cryopreserved in $30 \%$ sucrose overnight at $4.0^{\circ} \mathrm{C}$. Footpads were frozen, and $30 \mu \mathrm{m}$ floating sections were prepared. Tissue sections were blocked in $10 \%$ normal goat serum and $0.1 \%$ Triton $\mathrm{X}-100$ in PBS for $1 \mathrm{~h}$ at room temperature and then incubated in rabbit anti-PGP9.5 (1:1000; UltraClone) overnight at $4.0^{\circ} \mathrm{C}$. Sections were then incubated in goat anti-rabbit Alexa Fluor 488 (1:200; Invitrogen) and 4,6-diamidino-2-phenylindole dihydrochloride (DAPI) (1:1000) for $2 \mathrm{~h}$ at room temperature and mounted on gelatin-coated slides. Confocal images were obtained using a Carl Zeiss LSM 510 META upright confocal microscope, with a $40 \times$ air objective. Fiber number for thick (dermal papillae containing) and thin (non-dermal papillae containing) skin was determined to be the number of PGP9.5-labeled fibers penetrating the epidermis, measured over $225 \mu \mathrm{m}$ of length. Significance was calculated by Student's two-tailed $t$ test and two-way ANOVA.

Superficial and inner epidermal fibers were identified as PGP9.5positive fibers entering the stratum granulosum or not, respectively. Significance was calculated by Student's two-tailed $t$ test.

Cell culture. Compartmented chamber cultures (Campenot cultures) were prepared as described previously (Heerssen et al., 2004; PazyraMurphy et al., 2009). Briefly, dorsal root ganglia (DRGs) from embryonic day 15 (E15) rats were dissected and plated in the center compartment of a Teflon divider (Camp10; Tyler Research) (Campenot, 1982). Cultures were maintained in DMEM with 5\% horse serum, $1 \%$ penicillin-streptomycin, and $0.3 \mu \mathrm{M}$ cytosine arabinoside (AraC) at $37.0^{\circ} \mathrm{C}, 7.5 \% \mathrm{CO}_{2}$; neurotrophins were added to the cell body compartment at $10 \mathrm{ng} / \mathrm{ml} \mathrm{BDNF}$ (Peprotech) and $10 \mathrm{ng} / \mathrm{ml} \mathrm{NGF} \mathrm{(Peprotech)} \mathrm{and}$ to the axon compartment at a concentration of $100 \mathrm{ng} / \mathrm{ml} \mathrm{BDNF}$ and 100 $\mathrm{ng} / \mathrm{ml} \mathrm{NGF}$ for $3 \mathrm{~d}$. On day 4 , media were replaced and the $0.3 \mu \mathrm{m} \mathrm{AraC}$ was omitted. On day 6 , neurotrophins were removed from the cell body compartment and reduced to $1 \mathrm{ng} / \mathrm{ml}$ in axon compartments for 3-4 $\mathrm{d}$. For experiments involving neurotrophin stimulation, vehicle control $(100 \mathrm{ng} / \mathrm{ml} \mathrm{BSA}$ in PBS) or neurotrophins $(100 \mathrm{ng} / \mathrm{ml} \mathrm{NGF}+$ BDNF in vehicle) were applied to distal axon or cell body compartments or both (global stimulation) for the indicated time.

For mass cultures, $2.5 \times 10^{5}$ DRG neurons from E14 $b c l-w^{+/+}$and $b c l-w^{-1-}$ mice were plated in $\mathrm{p} 35$ culture dishes or $1 \times 10^{5} \mathrm{DRG}$ neurons on glass coverslips or glass-bottom 24 -well plates were grown for $2 \mathrm{~d}$ in neurotrophin-enriched (100 ng/ml NGF + BDNF) media with $0.9 \mu \mathrm{M}$ AraC, followed by $3 \mathrm{~d}$ in $50 \mathrm{ng} / \mathrm{ml}$ neurotrophins without AraC and without serum and then $1 \mathrm{~d}$ in $10 \mathrm{ng} / \mathrm{ml}$ neurotrophins with $0.9 \mu \mathrm{M}$ AraC. For axonal degeneration studies, DRGs were grown in either mass cultures or compartmented chamber cultures. For DRG explant cultures, whole DRGs from E14 $b c l-w^{+/+}$and $b c l-w^{-1-}$ mice were plated in glassbottom 24-well plates, two DRGs per well. Explants were maintained for $2 \mathrm{~d}$ in neurotrophin-enriched ( $100 \mathrm{ng} / \mathrm{ml} \mathrm{NGF}+\mathrm{BDNF}$ ) media with 0.9 $\mu \mathrm{M}$ AraC, followed by $1 \mathrm{~d}$ in $50 \mathrm{ng} / \mathrm{ml}$ neurotrophins without AraC and without serum. For compartmented chamber cultures, $5 \times 10^{4}$ DRG neurons from E14 $b c l-w^{+1+}$ and $b c l-w^{-/-}$mice were plated and maintained as described above. On day 5 , neurotrophins were reduced to $1 \mathrm{ng} / \mathrm{ml}$ in the cell body compartment and $10 \mathrm{ng} / \mathrm{ml}$ in the axonal compartment.

DRG cell counts. Stereology was performed as described previously (Hart and Terenghi, 2004). Briefly, animals were killed and perfused with PBS followed by $4 \%$ paraformaldehyde (PFA), and L4 and L5 DRGs were dissected, fixed in $4 \%$ PFA at $4.0^{\circ} \mathrm{C}$ for $4 \mathrm{~h}$, cryopreserved in $30 \%$ sucrose overnight at $4.0^{\circ} \mathrm{C}$, frozen, and serially sectioned at $30 \mu \mathrm{m}$ along the vertical axis (longitudinal axis of the ganglion). Every fourth section was blocked in 10\% normal goat serum and $0.1 \%$ Triton X-100 in PBS for $1 \mathrm{~h}$ at room temperature and then incubated in rabbit anti-Tuj1 (1:1000; Covance) overnight at $4.0^{\circ} \mathrm{C}$. Sections were incubated in goat anti-rabbit Alexa Fluor 488 (1:1000; Invitrogen) for $1 \mathrm{~h}$ at room temperature and then counterstained with DAPI for $1 \mathrm{~min}$. Sections were viewed with $40 \times$ air objective, and stereology was performed using the Optical Fractionator probe in the StereoInvestigator software with a $15 \mu \mathrm{m}$ high dissector centered between two guard zones, $50 \times 50 \mu \mathrm{m}$ counting frame, and $100 \times 100 \mu \mathrm{m}$ grid. The thickness of each slice was estimated as the average of three measurements of tissue thickness per slice. Neurons were counted if the nucleus of a Tuj1-positive cell fell within the boundaries of the counting frame. Total volume of the ganglion was estimated from careful delineation of the region of interest, sampling frequency, and number of sections obtained. Counting was performed blind to genotype, and significance was calculated by Student's two-tailed $t$ test.

The percentage of peptidergic and non-peptidergic neurons was assessed by counting the total number of calcitonin gene-related protein (CGRP)- or isolectin B4 (IB4)-positive cells, respectively, divided by the total number of DAPI-positive cells in the DRG. The average soma area was assessed using NIH ImageJ by drawing a border around the cell soma of CGRP- or IB4-positive cells with a visible nucleus.

Quantitative reverse transcription-PCR. RNA was harvested from DRG neurons in compartmented chamber cultures or in mass cultures using the RNAqueous-4PCR kit (Ambion). For in vivo analysis, DRG neurons from various ages of rats (E12 to 6 months) and $b c l-w^{+/+}$and $b c l-w^{-1-}$ mice were dissected, and RNA was extracted using TRIzol (Invitrogen). Reverse transcription (RT) was performed using the cDNA archive kit (Applied Biosystems) according to the specifications of the manufacturer. In rat DRGs, quantitative real-time RT-PCR was performed using Taqman Gene expression assays (Applied Biosystems) to assess the expression of $c$-fos (Rn02105452_s1), bcl-w (Rn00821025_s1), bcl-2 (Rn99999125_m1), and $b c l-x L$ (Rn00580568_g1). In mouse DRGs, quantitative real-time RT-PCR was performed using Taqman Gene expression assays for $b c l-w$ (Mm03053297_s1), bcl-2 (Mm02528810_s1), bcl-xL (Mm00437783_m1), bax (Mm00432050_m1), bak (Mm00432045_m1), bad (Mm00432042_ m1), bok (Mm00479422_m1), bid (Mm00626981_m1), bim (Mm01975020_ s1), and hrk (Mm01962376_s1). Data were normalized by the expression level of gapdh (glyceraldehyde-3-phosphate dehydrogenase) RNA for each sample (Applied Biosystems). For in vivo mRNA expression of Bcl-2 family members in rat DRGs, mRNA levels of each gene at each age were also 
normalized to the level of the gene at E14. For in vivo mRNA expression of Bcl-2 family members in $b c l-w^{+/+}$and $b c l-w^{-/-}$mouse DRGs, mRNA levels of each gene were normalized to mRNA levels in the $b c l-w^{+/+}$DRGs. Significance was calculated by $z$ test.

Western blotting. For analysis of Bcl-2 family member in DRG cell bodies and distal axons, E15 rat DRGs were grown in compartmented cultures as described. Cells and axons were lysed in non-ionic detergent, and protein lysates were separated by $7 \%$ SDS-PAGE and blotted with the following antibodies: rabbit anti-Bcl-w (1:200; Santa Cruz Biotechnology), rabbit anti-Bcl-2 (1:1000; Abcam), rabbit anti-Bcl-xL (1:1000; Cell Signaling Technology), and rabbit anti-actin (1:1000; Cell Signaling Technology). Bands were visualized with secondary antibodies conjugated to HRP (1:10,000; Bio-Rad) and SuperSignal chemiluminescent substrate kit. Using the Quantity One Software (Bio-Rad), protein bands were quantified and levels of Bcl-2 family members were normalized to actin, and then normalized distal axon protein levels were normalized to cell body protein levels to compare the ratio of distal axon to cell body Bcl-2 family member proteins.

For analysis of mitochondrial proteins, mass cultures of DRGs from E14 $b c l-w^{+/+}$and $b c l-w^{-/-}$mice were lysed in a non-ionic detergent. Protein lysates were separated by $7 \%$ SDS-PAGE and blotted with the following antibodies: rabbit anti-mitofusin 2 (MFN2) (1:1000; Sigma), mouse anti-optic atrophy 1 (OPA1) (1:1000; BD Transduction Laboratories), rabbit anti-dynamin-related protein 1 (DRP1) (1:1000; Novus Biologicals), rabbit anti-fission 1 (FIS1) (1:1000; MBL International), and rabbit anti-voltage-dependent anion selective channel (VDAC) (1: 1000; Cell Signaling Technology). Bands were visualized with secondary antibodies conjugated to HRP (1:10,000; Bio-Rad) and SuperSignal chemiluminescent substrate kit.

Immunostaining. For staining of DRGs, $b c l-w^{+/+}$and $b c l-w^{-1-}$ animals were killed and then perfused with PBS followed by $4 \%$ PFA, and L4 and L5 DRGs were dissected. DRGs were fixed in 4\% PFA at $4.0^{\circ} \mathrm{C}$ for $4 \mathrm{~h}$, cryopreserved in $30 \%$ sucrose at $4.0^{\circ} \mathrm{C}$ overnight, and frozen, and $30 \mu \mathrm{m}$ sections were prepared. For Bcl-w staining, sections were incubated in $100 \%$ methanol at $-20^{\circ} \mathrm{C}$, blocked in $10 \%$ normal goat serum and $0.1 \%$ TritonX-100 in PBS for $1 \mathrm{~h}$ at room temperature, and incubated in rabbit anti-Bcl-w (1:100; Stressgen) overnight at $4.0^{\circ} \mathrm{C}$. Sections were then incubated in biotinylated goat anti-rabbit (1:300; Vector Laboratories) for $1 \mathrm{~h}$ at room temperature, followed by streptavidin-conjugated Alexa Fluor 546 (1:500; Invitrogen) for $1 \mathrm{~h}$ at room temperature and then were counterstained with DAPI for $1 \mathrm{~min}$. For Tuj1 staining, sections were blocked in $10 \%$ normal goat serum and $0.1 \%$ Triton X-100 in PBS for $1 \mathrm{~h}$ at room temperature and incubated in mouse anti-Tuj1 (1:1000; Covance) overnight at $4.0^{\circ} \mathrm{C}$. Sections were then incubated in goat anti-mouse Alexa Fluor 488 (1:1000; Invitrogen) for $1 \mathrm{~h}$ at room temperature and counterstained with DAPI for $1 \mathrm{~min}$. For CGRP staining, sections were blocked in $10 \%$ normal goat serum and $0.1 \%$ Triton X-100 in PBS for $1 \mathrm{~h}$ at room temperature and incubated in rabbit anti-CGRP (1:100; Bachem) overnight at $4.0^{\circ} \mathrm{C}$. Sections were then incubated in goat anti-rabbit Alexa Fluor 488 (1:1000; Invitrogen) for $1 \mathrm{~h}$ at room temperature and counterstained with DAPI for $1 \mathrm{~min}$. For IB4 staining, sections were blocked in $1 \%$ bovine serum albumin and $0.1 \%$ Triton X-100 in PBS for $1 \mathrm{~h}$ at room temperature and incubated in biotinylated IB4 (1:50; Sigma) overnight at $4.0^{\circ} \mathrm{C}$. Sections were then incubated in streptavidin-conjugated Alexa Fluor 546 (1:500; Invitrogen) for $1 \mathrm{~h}$ at room temperature and counterstained with DAPI for 1 min. Images were obtained using NIS Imaging software and a $40 \times$ oil objective.

For staining of Bcl-2 family members in vitro, DRG neurons from E15 rats grown in mass cultures on p35 dishes for $5 \mathrm{~d}$ in the presence of neurotrophin were fixed in 4\% PFA for $20 \mathrm{~min}$, blocked in 10\% NGS and $0.1 \%$ Triton X-100 for $1 \mathrm{~h}$ at room temperature, and incubated in rabbit anti-Bcl-w (1:500; Biocarta), rabbit anti-Bcl-2 (1:1000; Abcam), or rabbit anti-Bcl-xL (1:1000; Cell Signaling Technology) overnight at $4.0^{\circ} \mathrm{C}$ and then anti-rabbit Alexa Fluor 546 (1:1000; Invitrogen) for $1 \mathrm{~h}$ at room temperature. Images were collected using NIS Elements software and a $40 \times$ air objective.
Axonal degeneration assay. DRGs from E14 $b c l-w+/+$ and $b c l-w^{-/-}$ mice were grown in the presence of neurotrophin in either a glassbottom 24-well plate for explant cultures or in compartmented chamber cultures. After $3 \mathrm{~d}$ in culture, explants were starved in plain DMEM for $24 \mathrm{~h}$ before fixation and staining. After $6 \mathrm{~d}$ in culture, the cell body compartment was maintained in $100 \mathrm{ng} / \mathrm{ml} \mathrm{NGF}+\mathrm{BDNF}$, and the axonal compartmented was starved in plain DMEM for $24 \mathrm{~h}$ before fixation and staining. Explant and compartmented chamber cultures were fixed in $4 \%$ PFA for $20 \mathrm{~min}$, blocked in $10 \%$ NGS and $0.1 \%$ Triton X-100 for $1 \mathrm{~h}$ at room temperature, incubated with rabbit anti-Tuj1 (1:1000; Covance) overnight at $4.0^{\circ} \mathrm{C}$ and then with goat anti-rabbit Alexa Fluor 488 (1:1000; Invitrogen) for $1 \mathrm{~h}$ at room temperature, and counterstained with DAPI. Images of distal axons were obtained using a $20 \times$ objective and NIS Elements software. To quantify axonal degeneration, we used the method described by Sasaki et al. (2009). Images were binarized so that axonal areas were converted to black and background areas were converted to white. To detect fragmented (degenerating) axons, the particle analyzer function of NIH ImageJ software was used to determine the area of the fragments (size, 5-1000 pixels). The degeneration index was then calculated as the ratio of the area of fragmented axons over the total axon area. Statistical significance was determined by Student's two-tailed $t$ test.

ATP luciferase assay. DRG neurons from E14 bcl-w $+1+$ and $b c l-w^{-/-}$ mice were grown on glass coverslips in the presence of neurotrophin. After $5 \mathrm{~d}$ in culture, DRGs were starved for $2 \mathrm{~h}$ and then stimulated with neurotrophin (100 ng/ml NGF + BDNF) or vehicle for $2 \mathrm{~h}$. Cells were then scraped in 1:5 TBS, $100 \mu \mathrm{l}$ of lysate was transferred to a white OptiPlate-96 (PerkinElmer Life and Analytical Sciences), and $25 \mu \mathrm{l}$ of lysate was saved for protein concentration measurements. An equal amount of ATPlight 1step substrate (PerkinElmer Life and Analytical Sciences) was added to each well of cell lysate and mixed for $10 \mathrm{~min}$, and luminescence was detected using a FLUOstar Optima plate reader. In these experiments, neurotrophin stimulation was found to have no significant effect on ATP levels for either $b c l-w^{+/+}$or $b c l-w^{-1-}$ neurons, and thus these groups were combined for analysis. Luminescence was first normalized to protein concentration, measured by Micro-BCA Protein Assay kit (Thermo Fisher Scientific). Luminescence normalized by protein concentration was then normalized to the average of $b c l-w^{+/+}$ neurons for each experiment, and significance was calculated by $z$ test.

Mitochondrial labeling. For measurements of mitochondrial size and distribution, mass cultures of $b c l-w^{+/+}$and $b c l-w^{-/-}$DRG neurons grown on glass coverslips were labeled using MitoTracker Red CMXRos (Invitrogen). MitoTracker was applied to cells (1:2000-1:5000) for 30 min, and then cells were rinsed in HBSS, fixed in 4\% PFA for $10 \mathrm{~min}$, blocked in $10 \%$ normal goat serum and $0.1 \%$ Triton X-100 for $1 \mathrm{~h}$ at room temperature, incubated in rabbit anti-Tuj1 (1:1000; Covance) overnight at $4.0^{\circ} \mathrm{C}$, and incubated in goat anti-rabbit Alexa Fluor 488 (1:1000; Invitrogen) for $1 \mathrm{~h}$ at room temperature. Images of mitochondria in Tuj1-labeled axons were obtained with a $100 \times$ oil objective. Mitochondrial length was measured in NIS Elements Image software by an observer blind to genotype. Significance was calculated by Student's twotailed $t$ test. Mitochondrial distribution was measured in NIS Elements Image software by counting the number of mitochondria in a measured length of axon by an observer blind to genotype. The number of mitochondria per micron of axon length expressed as a cumulative percentage was analyzed by Kolmogorov-Smirnov test.

For measurement of mitochondrial membrane potential, mass cultures of $b c l-w^{+/+}$and $b c l-w^{-/-}$DRG neurons grown on glass-bottom 24-well plates were labeled using tetramethylrhodamine ethyl ester (TMRE) (Invitrogen). TMRE was applied to cells (100 $\mu \mathrm{M})$ for $20 \mathrm{~min}$, and then cells were rinsed in media and imaged live using a $60 \times$ oil objective. Fluorescence intensity of both cell body and axonal mitochondria was measured by dividing the fluorescence intensity of each mitochondria by the average background fluorescence intensity of the cytoplasm within each picture. Fluorescence intensity was measured using NIH ImageJ software, by an observer blind to genotype. Statistical significance was calculated by Student's two-tailed $t$ test. 
A

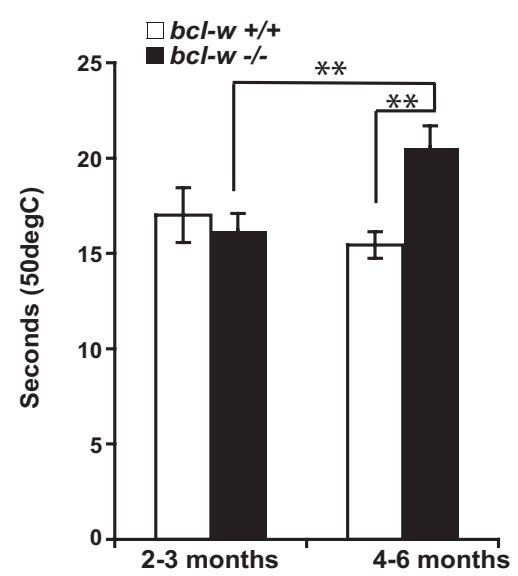

B

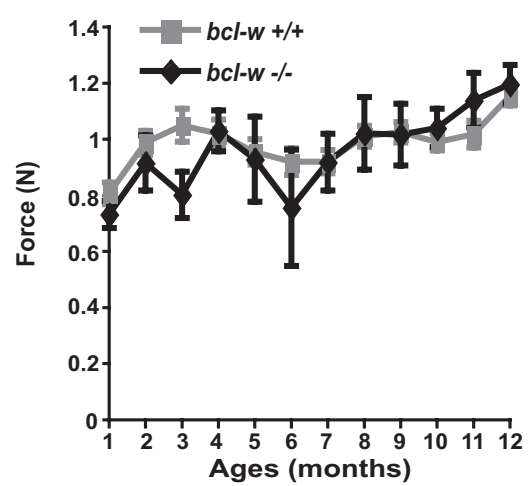

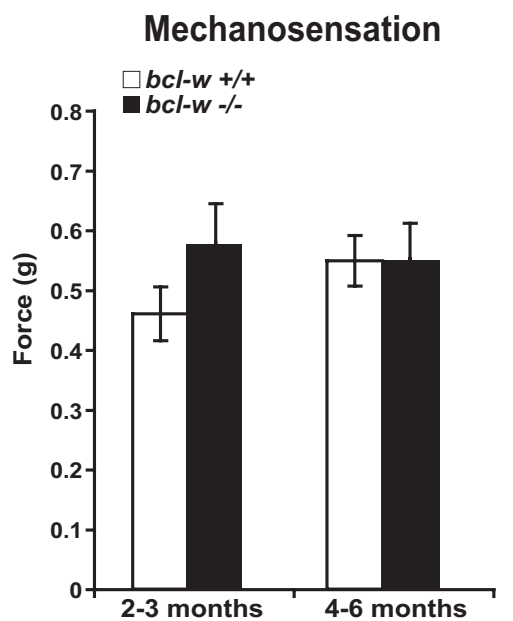

Hindlimb

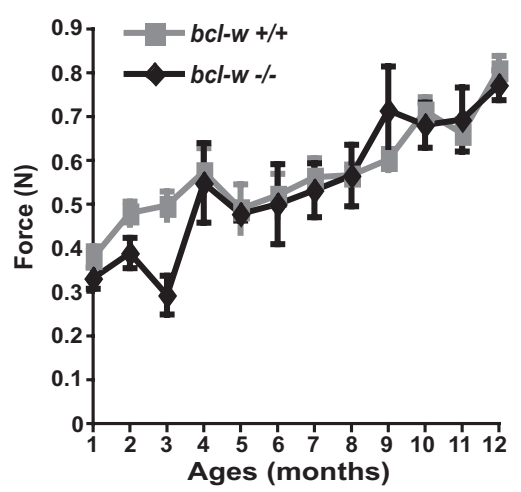

Figure 1. $B C l-w^{-1-}$ mice show progressive deficits in behavioral response to thermal stimulation. $\boldsymbol{A}$, Behavioral response to thermal and mechanical stimulation was measured in $b \mathrm{Cl}-w^{+/+}$and $b \mathrm{Cl}^{-w^{-/-}}$mice using the hotplate $\left(50.0^{\circ} \mathrm{C}\right)$ and von Frey assays, respectively. $b c l_{-w^{-/-}}$mice show no impairment in response to thermal stimulation at $2-3$ months of age $(n=16$ $\left.b c l-w^{+/+} ; n=17 b c l-w^{-1-}\right)$. By $4-8$ months of age, response to thermal stimulation was impaired in $b c l-w^{-1-}$ mice. ${ }^{* *} p<$ $\left.0.01 ; n=21 b \mathrm{bl}-w^{+/+} ; n=13 \mathrm{bcl}-w^{-/-}\right)$. There is no difference in response to mechanical stimulation as measured by force to elicit hindpaw withdrawal $\left(n=16 \mathrm{bcl}-w^{+/+} ; n=17 \mathrm{bcl}-w^{-/-}\right.$for $2-3$ months of age; $n=21 \mathrm{bcl}-w^{+/+} ; n=12 \mathrm{bcl}-w^{-/-}$at $4-8$ months of age; one statistically defined outlier removed from analysis in $b \mathrm{Cl}^{-w^{-/-}} 4-8$ month group). $\boldsymbol{B}$, Grip strength was tested in $b \mathrm{Cl}-w^{+/+}$and $b c 1-w^{-/-}$mice using a digital grip strength meter. $b c l-w^{-/-}$mice show no impairment in forelimb or hindlimb grip strength through 12 months $\left(n=11-34 b \mathrm{bl-w^{+/+ }} ; n=2-9 \mathrm{bcl-w^{-/- }}\right)$.

\section{Results}

$b c l-w^{-/-}$mice show progressive nociceptor sensory neuropathy

Bcl-w is highly expressed in the nervous system (Hamnér et al., 1999; O'Reilly et al., 2001), and Bcl-w expression in neurons is regulated by neurotrophins (Pazyra-Murphy et al., 2009). However, previous studies on $b c l-w^{-1-}$ mice focused predominantly on the reproductive organs and gastrointestinal tract (Print et al., 1998; Ross et al., 1998; Pritchard et al., 2000; Bernal et al., 2006). Here, we use $b c l-w^{-1-}$ mice (Ross et al., 1998) to analyze the role of Bcl-w in a neurotrophin-dependent population, DRG sensory neurons. Because DRG neurons relay diverse forms of sensory input, including information about temperature, mechanical stimulation, and proprioception, behavioral studies can be used to address DRG function. At 2-3 months of age, $b c l-w^{-1-}$ mice show normal responses to noxious thermal stimulation, as measured by latency to hindpaw withdrawal in the hotplate assay $\left(50.0^{\circ} \mathrm{C}\right)$, and normal responses to noxious mechanical stimulation, as measured by the force necessary to elicit hindpaw withdrawal in the von Frey assay. However, by 4-8 months of age, $b c l-w^{-1-}$ mice exhibit decreased responses to nox- ious thermal stimulation, demonstrated by increased latency to hindpaw withdrawal in the hotplate assay. At this age, impairment of pain sensation is selective for noxious thermal stimulation, because there is no decrease in response to noxious mechanosensation (Fig. $1 \mathrm{~A}$ ). Furthermore, $b c l-$ $w^{-\prime-}$ mice show no deficit in forelimb or hindlimb grip strength at any age (Fig. $1 B$ ). Grip strength testing measures both proprioception, as mice are required to grasp a wire grid, and motor neuron function, as mice are required to resist an opposing force by pulling with their limb muscles. Thus, $b c l-w^{-1-}$ mice exhibit a selective, progressive impairment in thermal nociception.

Responses to noxious thermal stimuli are initiated by unmyelinated free nerve endings terminating in the epidermis. We examined epidermal innervation in the hindpaws of $b c l-w^{-/-}$mice at asymptomatic (2 month) and symptomatic (6 month) stages. In young $b c l-w^{-1-}$ mice, epidermal innervation in areas of both thin (nondermal papillae-containing) and thick (dermal papillae-containing) skin is normal. However, in older $b c l-w^{-1-}$ mice, epidermal innervation is significantly reduced in both thin and thick skin compared with $b c l$ $w^{+/+}$mice (Fig. $2 A-D$ ). Furthermore, $b c l$ $w^{-/-}$mice display decreased innervation of both superficial and inner epidermal layers of the skin (Fig. 2E,F). Because nonpeptidergic fibers primarily innervate the superficial layer whereas peptidergic fibers innervate the inner layer (Zylka et al., 2005), these data suggest that $\mathrm{Bcl}-\mathrm{w}$ prevents dying back of both peptidergic and nonpeptidergic axons. Thus, in agreement with the agedependent decline in thermosensation in $b c l-w^{-1-}$ mice, we find a progressive loss of nociceptor innervation of the skin.

Bcl-2 family members, including $\mathrm{Bcl}-\mathrm{w}$, cooperate with one another to regulate the apoptotic cascade. To investigate any compensatory alterations in gene expression, we examined mRNA levels of these related genes in $b c l$ $w^{-1-}$ DRGs. We find no compensatory alterations in mRNA levels of other Bcl-2 family members, suggesting that observed differences between $b c l-w^{+1+}$ and $b c l-w^{-1-}$ DRG sensory neurons can be directly attributed to loss of Bcl-w (Fig. 3).

\section{Sensory neuropathy in $b c l-w^{-/-}$mice occurs without cell body loss}

Some sensory neuropathies involve loss of both cell body and axon, whereas others are primarily characterized by axonal degeneration without cell body loss (for review, see Raff et al., 2002; Vickers et al., 2009). As shown above, loss of Bcl-w leads to degeneration of axons innervating the skin. To determine whether there is also degeneration of the cell soma, we used stereological techniques to count the number of neuronal cell bodies in $b c l$ $w^{+/+}$and $b c l-w^{-/-}$DRGs at 6 months of age, when axonal degeneration and behavioral deficits are clearly evident. Stereological counting methods avoid many of the technical 
confounds of counting neurons in thin, two-dimensional sections, including over-representation of larger cells, underrepresentation of smaller cells, and torn "caps" of cells at the edges of the slice (for review, see Hart and Terenghi, 2004). In L4 and L5 DRGs, the axons from which project to the footpad, we find no decrease in neuronal cell number in $b c l-w^{-/}$mice at 6 months of age (Fig. $4 A, B$ ), although in 6-month-old $b c l-w^{-/-}$mice, there is a $23 \%$ decrease in nociceptor innervation in thin skin (Fig. 2C) (11 fibers/225 $\mu \mathrm{m}$ in $b c l-w^{+/+}$vs 8.5 fibers/225 $\mu \mathrm{m}$ in $b c l-$ $w^{-1-}$ ) and a $36 \%$ decrease in nociceptor innervation in thick skin (Fig. 2D) (12.5 fibers $/ 225 \mu \mathrm{m}$ in $b c l-w^{+/+}$vs 8 fibers $/ 225$ $\mu \mathrm{m}$ in $\left.b c l-w^{-/-}\right)$. Nociceptors terminating in epidermal free nerve endings comprise $\sim 40-50 \%$ of the total DRG population (for review, see Ernsberger, 2009); therefore, we estimate that, if neuronal cell body loss corresponded to axonal loss in $b c l-w^{--}$animals, we would expect to see between 9 and $18 \%$ loss of DRG cell bodies. To ensure that we have counted DRGs from a sufficient number of animals to reliably detect a difference of this magnitude, we performed a retrospective power analysis. This analysis revealed that, with the number of animals used in this study $\left(n=8 \mathrm{bcl-w^{+/+ }} ; n=7\right.$ $b c l-w^{-I-}$ ), we would be able to detect a $6 \%$ difference between groups in L4 DRG counts, and a 7\% difference between groups in L5 DRG counts. Therefore, we can exclude the possibility that the decreased innervation in 6-month-old $b c l-w^{-/-}$mice is attributable to a corresponding reduction in DRG cell body number.

Analysis of sensory neuron subpopulations revealed no difference in the relative numbers or the morphology of peptidergic and nonpeptidergic nociceptor neurons, as assessed by staining DRG neurons for CGRP and IB4 (Fig. 4C,D), respectively. The CGRP-positive neurons represent $10.75 \pm 1.81 \%$ of DRG neurons in $b c l-w^{+/+}$and $9.23 \pm 0.97 \%$ of DRG neurons in $b c l-w^{-1-}$, whereas IB4-positive neurons represent $15.09 \pm 0.84 \%$ of DRG neurons in $b c l-w^{+/+}$and $13.8 \pm 0.68 \%$ of DRG neurons in $b c l-w^{-/-}$mice. The average soma area for CGRP-positive neurons was $244.8 \pm 21.1 \mu \mathrm{m}^{2}$ in $b c l-w^{+/+}$and $214.4 \pm 15.7 \mu \mathrm{m}^{2}$ in $b c l-w^{-1-}$ mice, and for IB4-positive neurons, average soma area was $311.7 \pm 28.5 \mu \mathrm{m}^{2}$ in $b c l-w^{+/+}$and $323.5 \pm 21.2 \mu \mathrm{m}^{2}$ in $b c l-w^{-1-}$ mice. Not surprisingly, there is no difference in DRG cell body number between $b c l-w^{+/+}$and $b c l-w^{-/-}$mice at 2 months of age (data not shown). Together, these results demonstrate that $b c l-w^{-1-}$ mice are not deficient in the number, the subtype, or the morphology of nociceptor cell bodies, and the observed phenotypes are a result of a primary axonal degeneration.

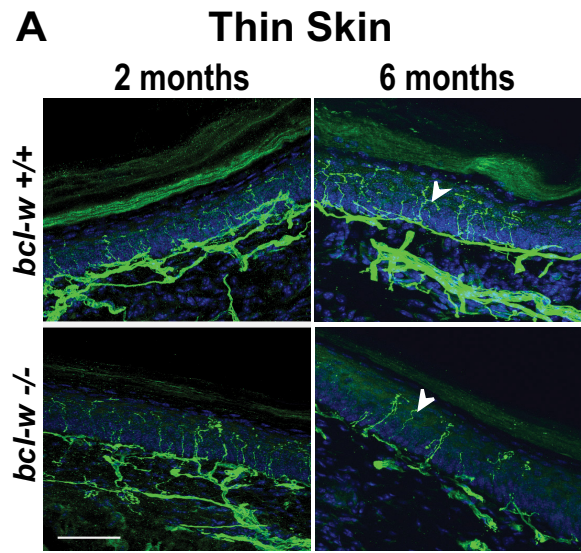

\section{Thin Skin}
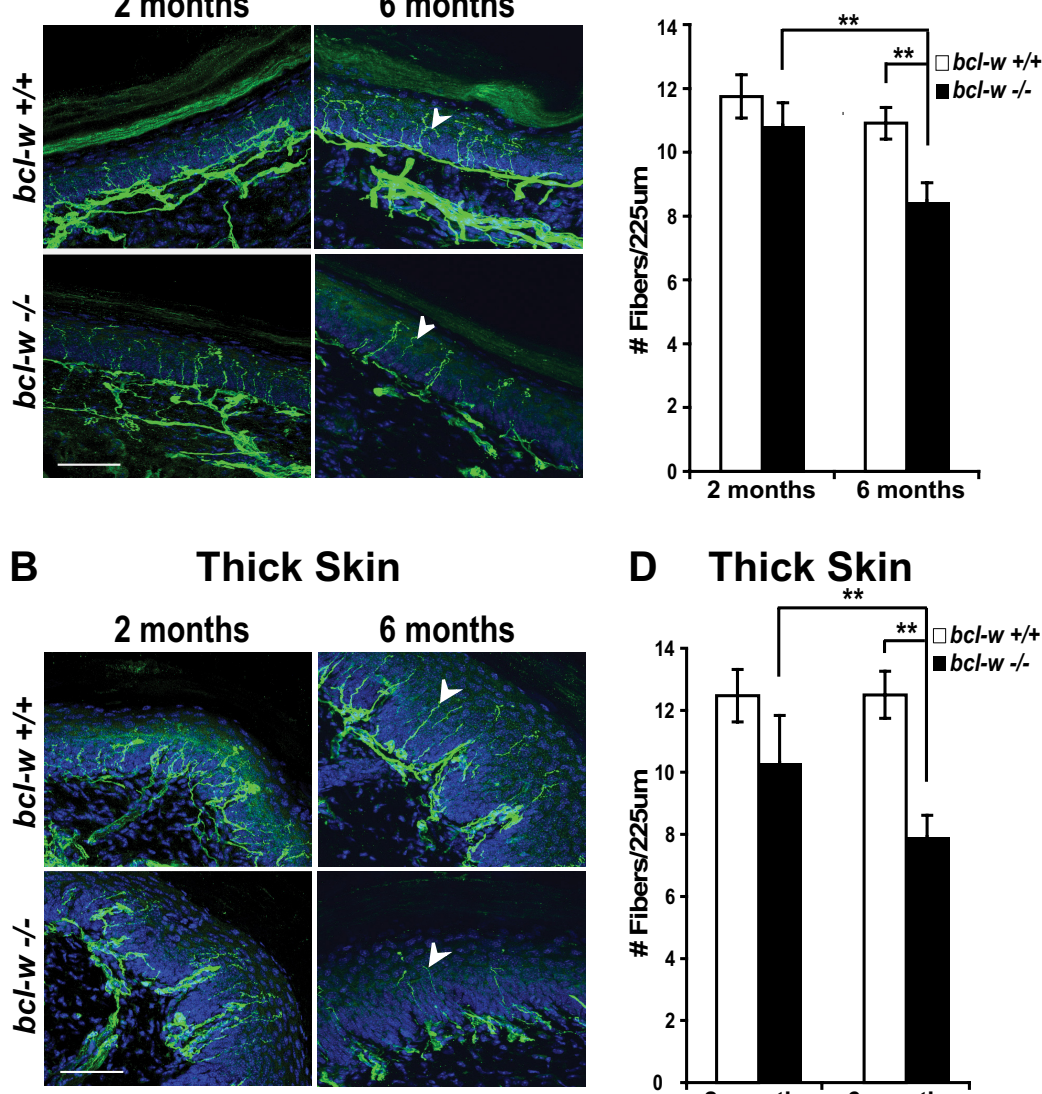

\section{Thick Skin}

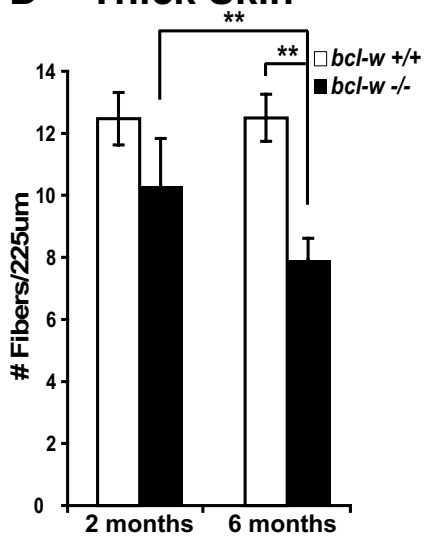

E Thin Skin

F Thick Skin

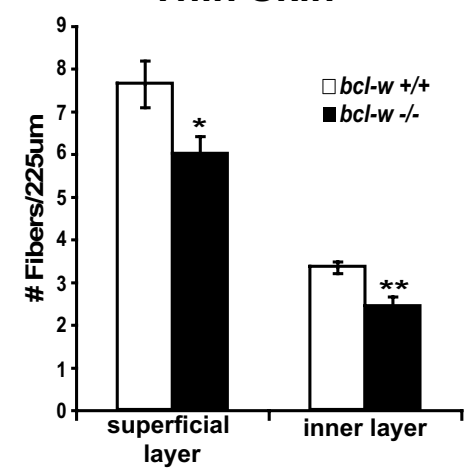

Figure 2. $\quad b \mathrm{cl}-w^{-1-}$ mice show progressive loss of small fiber nociceptor innervation. $\boldsymbol{A}, \boldsymbol{B}, b \mathrm{cl}-w^{-1-}$ mice show normal epidermal nociceptor innervation in both thin and thick skin as revealed by PGP9.5 staining (white arrowheads) at 2 months old. By 6 months old, $b \mathrm{Cl}_{-} \mathrm{w}^{-1-}$ mice show decreased nociceptor innervation in both thin and thick skin. Scale bars, $50 \mu \mathrm{m} . \boldsymbol{C}, \boldsymbol{D}$, Quantification of fiber number per $225 \mu \mathrm{m}$ of epidermal length shows a significant decrease in fiber innervation in $b \mathrm{cl}-w^{-/-}$mice at 6 months old $\left({ }^{*} p<0.05 ;{ }^{* *} p<0.01 ; n=3\right.$ animals per genotype, $3-5$ sections examined per animal at each age, for both thick and thin skin). $\boldsymbol{E}, \boldsymbol{F}, \mathrm{A}$ significant decrease in fibers innervating both the superficial and inner layers of thin and thick skin seen in $b c l-w^{-/-}$mice at 6 months old $\left({ }^{*} p<0.05 ;{ }^{* *} p<0.01\right)$.

Bcl-w differs from Bcl-2 and Bcl-xL in DRG sensory neurons We previously demonstrated that $b c l-w$ is one of a set of retrograde response genes that are preferentially induced by distal axon stimulation with neurotrophins (Pazyra-Murphy et al., 2009). We suggest that these retrograde response genes in aggregate support the survival of neurons once they are integrated into a functional circuit. In vivo, Bcl-w is expressed by a majority of DRG sensory neurons detected by Tuj1 staining (Fig. 5A). Bcl-w is a member of the larger Bcl-2 family of proteins and is most 


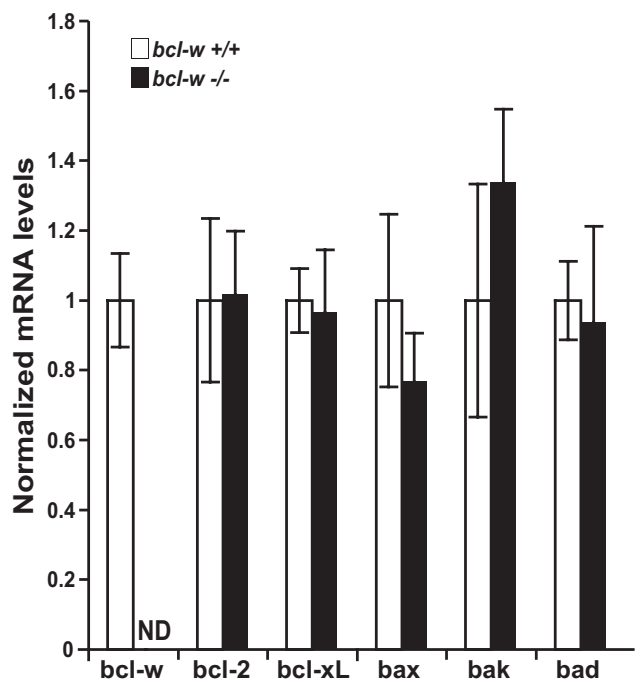

Figure 3. Dorsal root ganglia from $b c l-w^{-1-}$ mice do not show compensatory alterations in mRNA levels of $b c \mid-2$ family members. Quantitative RT-PCR of $b c l-2$ family genes shows that $b c l-w$ is the only mRNA significantly altered in DRGs of $b c l-w^{-/}$mice. Data represent mean \pm SEM for at least three animals, samples run in triplicate. Values are normalized to $b \mathrm{cl}-w^{+/+}$ value for each gene. ND, Not detected. closely related to the other anti-apoptotic members Bcl-2 and $\mathrm{Bcl}-\mathrm{xL}$. We therefore asked whether there are distinctive features of $\mathrm{Bcl}-\mathrm{w}$ regulation and localization that might explain the progressive sensory neuropathy with axonal degeneration observed in $b c l-w^{-1-}$ animals. We used compartmented chamber cultures, which recapitulate the spatial separation between cell bodies and axons found in vivo, to allow us to selectively apply neurotrophins to distal axons or cell bodies. In contrast to $b c l-w$ mRNA, which is selectively induced after distal axon stimulation by neurotrophins but is not induced after global stimulation, $b c l-2$ mRNA is upregulated after global stimulation and not distal axon stimulation. $B c l-x L$ mRNA shows no regulation by neurotrophin stimulation (Fig. 5B).

These in vitro studies show that neurotrophins applied to distal axons of sensory neurons increase $b c l-w$ expression. In vivo, neurotrophins released from target tissues provide selective distal axon stimulation. Therefore, we examined the time course of $b c l-w$ mRNA expression in vivo to determine whether $b c l-w$ is upregulated at a time when DRG axons reach their peripheral targets. As shown in Figure $5 C, b c l-w$ mRNA increases in late embryonic and early postnatal life. Consistent with the timing of $b c l-w$ expression in other tissues, $b c l-w$ expression in DRGs remains at high levels in adulthood. In contrast, $b c l-2$ levels do not increase with age. Although $b c l-x L$ levels increase late postnatally and in adulthood, it is likely that factors other than targetderived neurotrophins are mediating this increase because $b c l-x L$ mRNA does not appear to be regulated by neurotrophins. Thus, the disneurons. Therefore, we examined the subof $\mathrm{Bcl}-2$ and $\mathrm{Bcl}-\mathrm{xL}$ is highest in the cell important differences between Bcl-w and

high levels in adulthood, consistent with tinctive time course of $b c l-w$ expression is consistent with a model in which $b c l-w$ is selectively upregulated when DRG axons reach their targets in the periphery and encounter target-derived neurotrophins.

Intriguingly, the neuropathy found in $b c l-w^{-/-}$animals involves a dying back of axons rather than a loss of cell bodies, suggesting that Bcl-w predominantly functions in the long axons of sensory cellular localization of Bcl-w and compared this with the localization of $\mathrm{Bcl}-2$ and Bcl-xL in DRG neurons. As shown by both immunoblotting and immunostaining, Bcl-w is highly expressed in both cell bodies and distal axons of sensory neurons (Fig. $5 D, E$ ). In contrast, expression bodies, and significantly lower levels are detected in axons.

These results regarding regulation and localization of anti-apoptotic Bcl-2 family members in DRG neurons demonstrate the closely related proteins $\mathrm{Bcl}-2$ and $\mathrm{Bcl}-$ $\mathrm{xL} . \mathrm{Bcl}-\mathrm{w}$ is regulated by neurotrophin stimulation of the distal axon and is initially expressed in vivo when sensory axons reach the periphery and encounter target-derived neurotrophins. $\mathrm{Bcl}-\mathrm{w}$ mRNA expression continues to rise during the postnatal period and remains at

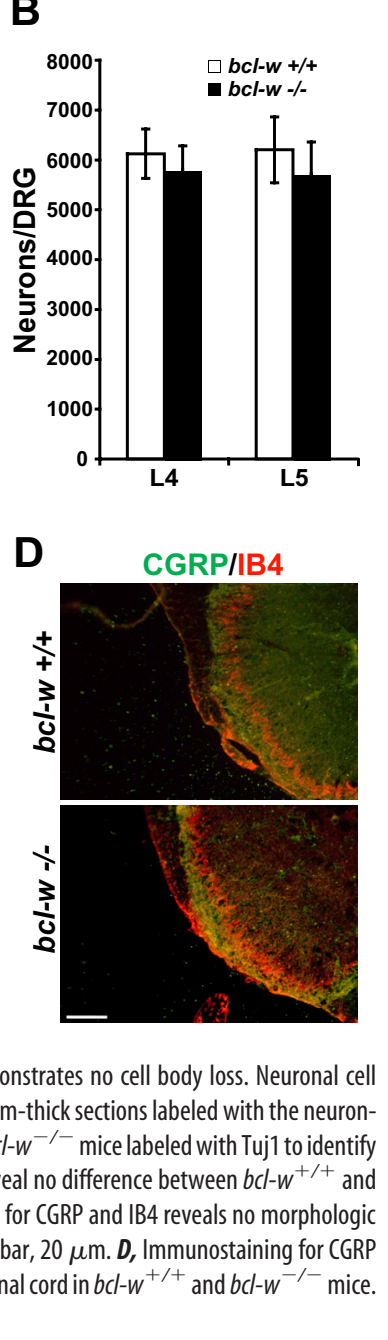

Figure 4. Stereological counting of neurons in 6-month-old $b \mathrm{cl}-w^{-1-}$ mice demonstrates no cell body loss. Neuronal cell counts were obtained using an 0ptical Fractionator Probe (Stereolnvestigator) in 30- $\mu \mathrm{m}$-thick sections labeled with the neuronspecific marker Tuj1. A, Representative images of $\mathrm{L} 4$ and $\mathrm{L} 5 \mathrm{DRGs}$ from $b \mathrm{Cl}-w^{+/+}$and $b \mathrm{Cl}-w^{-/-}$mice labeled with Tuj 1 to identify neurons used for counting. Scale bar, $20 \mu \mathrm{m}$. $\boldsymbol{B}$, Stereological neuronal cell counts reveal no difference between $b \mathrm{Cl}-w^{+/+}$and $b c l-w^{-1-}$ DRGs $\left(p>0.05 ; n=8 b c l-w^{+1+} ; n=7 b{\mathrm{cl}-w^{-1-}}\right)$. C, Immunostaining for CGRP and IB4 reveals no morphologic changes or loss of peptidergic or nonpeptidergic nociceptors in $b c l-w^{-/-}$DRGs. Scale bar, $20 \mu \mathrm{m}$. D, Immunostaining for CGRP (green) and IB4 (red) reveals no difference in the central process that innervates the spinal cord in $b c l-w^{+/+}$and $b c l-w^{-/-}$mice. Scale bar, $20 \mu \mathrm{m}$. 
A
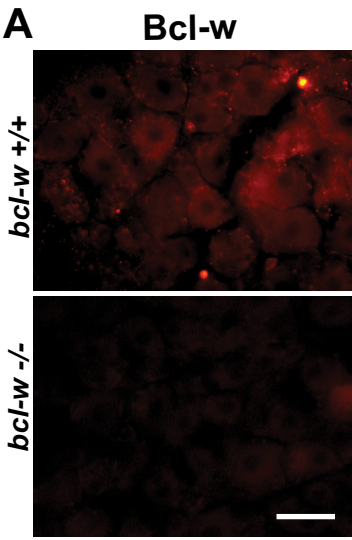

B

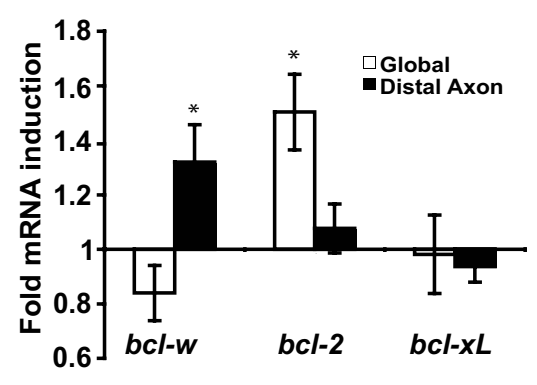

D

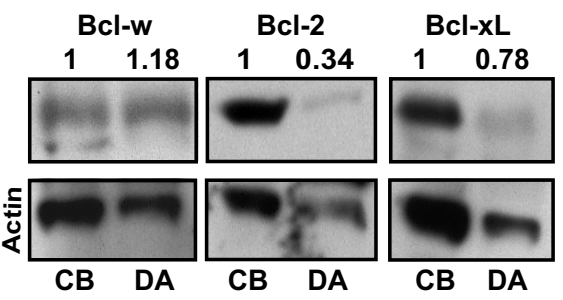

Tuj1
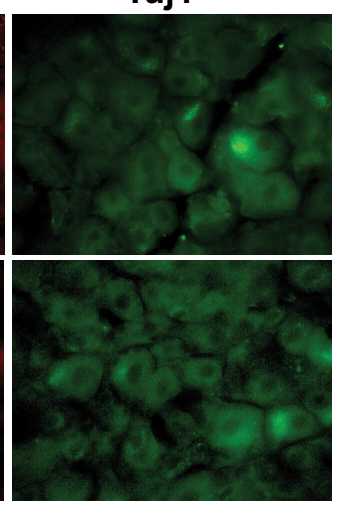

DAPI

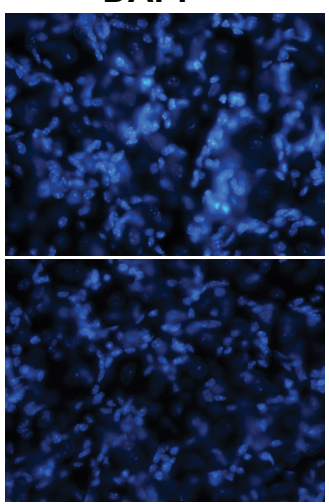

Merge

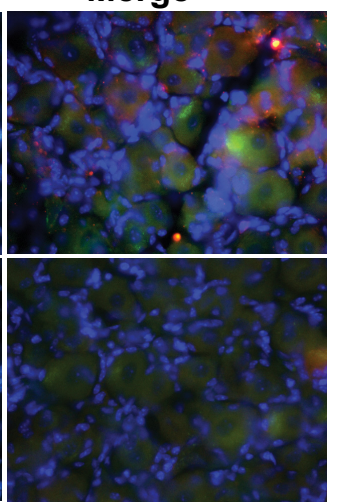

C

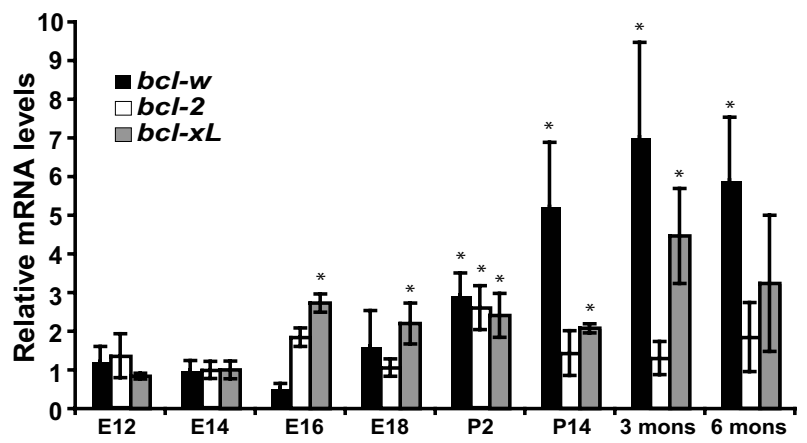

E

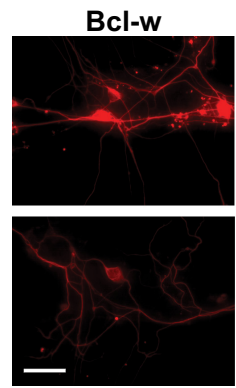

Bcl-2

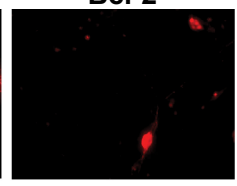

Bcl-xL
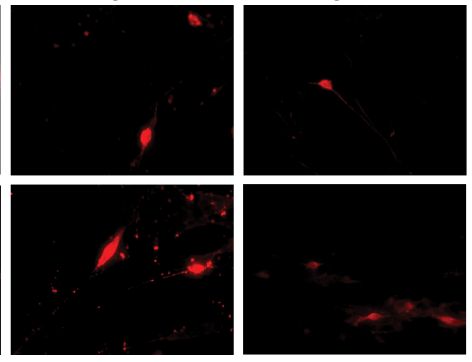

Figure 5. BCl-w shows unique regulation and localization in DRG sensory neurons. $A, B C l-w(r e d)$ is expressed in the majority of Tuj1-positive (green) DRG neurons. Scale bar, $20 \mu \mathrm{m}$. Specificity of the $\mathrm{BCl}-\mathrm{w}$ antibody is demonstrated by absence of staining in $b c l-w^{-1-}$ DRG. $B, b c l-w \mathrm{mRNA}$ is upregulated by distal axon stimulation with neurotrophins (100 $\mathrm{ng} / \mathrm{ml} \mathrm{NGF}+\mathrm{BDNF}$ for $2 \mathrm{~h}$ vs vehicle treatment) but not by global stimulation. In contrast, $b c(-2 \mathrm{mRNA}$ is upregulated by global stimulation, and $b c(-x L \mathrm{mRNA}$ is not affected by neurotrophin stimulation. Data represent mean \pm SEM for five experiments (data analyzed by $z$ test; ${ }^{*} p<0.05$, for a difference from 1). C, In vivo, bcl-w mRNA is upregulated at late embryonic stages and expression continues through adulthood. Data represent mean \pm SEM for three to six animals per age, normalized to E14 values for each gene (data analyzed by $z$ test; ${ }^{*} p<0.05$, for a difference from 1 ), $b c l-2$ mRNA levels are stable over time, and $b c$ - $x L$ levels increased in late embryonic and postnatal stages. $\boldsymbol{D}$, Immunoblotting with antibodies specific to BCl-w, BCl-2, or BCl-xL reveal that BCl-w is expressed at high levels in axons, whereas $\mathrm{BCl}-2$ and $\mathrm{BCl}-\mathrm{xL}$ are predominantly localized to cell bodies. Normalized relative band density of $\mathrm{BCl}-2$ family member/actin show a distal axon to cell body ratio of $1.18 \pm 0.03$ for $\mathrm{BCl}-\mathrm{w}$, $0.34 \pm 0.07$ for $\mathrm{BCl}-2$, and $0.78 \pm 0.08$ for $\mathrm{BCl}-\mathrm{xL}(n=3) . E$, Immunostaining of DRGs grown in mass cultures with antibodies specific for $\mathrm{BCl}-\mathrm{w}, \mathrm{BCl}-2$, or $\mathrm{BCl}-\mathrm{xL}$ reveal that $\mathrm{BCl}-\mathrm{w}$ is expressed in both axons and cell bodies, whereas BCl-2 and BCl-xL are predominantly localized to cell bodies. Scale bar, $10 \mu \mathrm{m}$.

the observed age-related progressive neuropathy of $b c l-w^{-/-}$ mice. Furthermore, Bcl-w protein is highly expressed in axons. Thus, the observed axonopathy without cell body loss in $b c l-w^{-/-}$ mice suggests that $\mathrm{Bcl}-\mathrm{W}$ plays a specialized role in axonal viability.

\section{bcl- $w^{-/-}$neurons undergo axonal degeneration in vitro}

Because $b c l-w^{-1-}$ mice undergo age-related axonopathy of sensory neurons and Bcl-w is relatively enriched in axons compared to cell bodies, we analyzed axonal degeneration in both DRG explants and compartmented chamber cultures from $b c l-w^{+/+}$ and $b c l-w^{-1-}$ mice (Sasaki et al., 2009). Under neurotrophinenriched conditions, neither $b c l-w^{+/+}$nor $b c l-w^{-/-}$cultures ex- hibit significant axonal degeneration (data not shown). However, in response to $24 \mathrm{~h}$ of starvation, during which cells are cultured without neurotrophins or serum, $b c l-w^{-1-}$ neurons exhibit significantly more axonal degeneration than $b c l-w^{+/+}$neurons (Fig. $6 A-D) . b c l-w^{-1-}$ animals have normal epidermal innervation at young ages and only undergo axonal degeneration as they age. In these cultures derived from embryonic neurons, we postulate that the starvation condition acts as a stressor, similar to aging, to elicit axonal degeneration.

In explant cultures, axonal degeneration might represent the first visible manifestation of overall cellular deterioration. Therefore, to determine whether bcl-w has a specialized function in axonal viability, we plated DRG neurons from $b c l-w^{+/+}$or $b c l$ - 
A

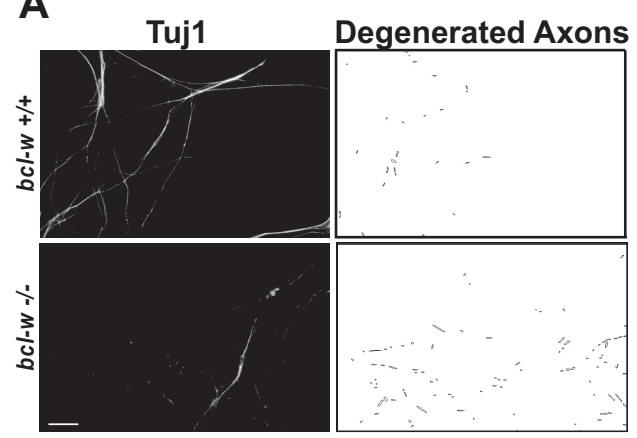

B

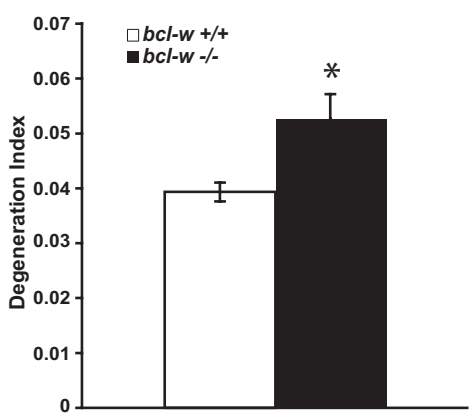

C

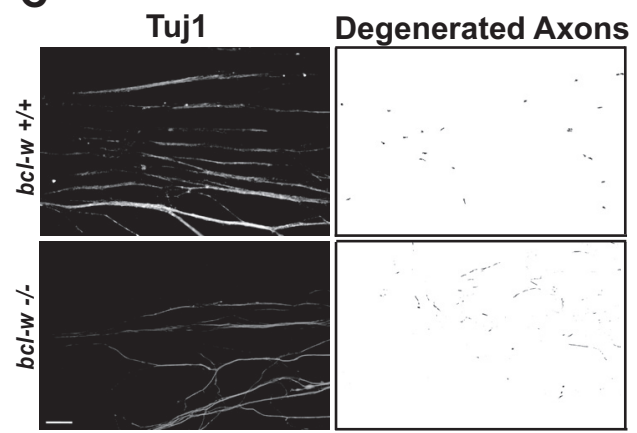

\section{D}

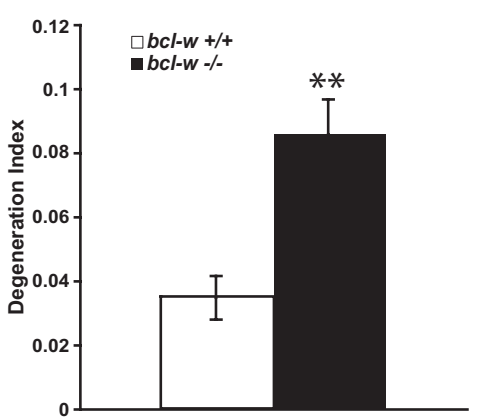

Figure 6. $\quad b c l-w^{-1-}$ DRG sensory neurons undergo axonal degeneration in vitro. $A, C$, Representative images of Tuj1-labeled axons from $b c l-w^{+/+}$and $b c l-w^{-/-}$DRG explant and compartmented chamber cultures, respectively. Degenerated axon pictures show fragmented axons defined by the Analyze Particle function in NIH ImageJ software. $B, D$, Quantification of axonal degeneration as measured by the degeneration index (ratio of area of fragmented axons to total axon area) shows significantly more axonal degeneration in $b c-w^{-/-}$axons after $24 \mathrm{~h}$ of starvation (for explant cultures, ${ }^{*} p<0.005, n=50$ axonal fields from $4 b c 1-w^{+/+}$ animals, $n=18$ axonal fields from $5 \mathrm{bcl}-\mathrm{w}^{-/-}$animals; for compartmented chamber cultures, ${ }^{* *} p<0.001, n=36$ axonal fields from $5 \mathrm{bcl-w^{+/+ }}$ animals, $n=39$ axonal fields from $4 b c \mathrm{l}^{-1-}$ animals).

$w^{-1-}$ littermates in compartmented chamber cultures. Distal axons were maintained with neurotrophins for $6 \mathrm{~d}$ to allow bcl-w expression in wild-type cells, and distal axons were deprived of neurotrophins and serum while cell bodies were maintained in neurotrophins. Under these conditions, there was dramatically more degeneration in $b c l-w^{-1-}$ than in wild-type axons (Fig. $6 D)$, although there was no difference in cell soma apoptosis (condensed nuclei, $3.0 \pm 0.2 \%$ in $b c l-w^{+/+}$and $3.6 \pm 0.3 \%$ in $\left.b c l-w^{-/-}\right)$. Thus, bcl-w has a specialized role in preventing the dying back of axons.

\section{$b c l-w^{-/-}$neurons exhibit abnormal mitochondrial morphology and function}

$\mathrm{Bcl}-\mathrm{w}$ is associated with intracellular membranes, particularly the mitochondrial membrane (O'Reilly et al., 2001). We therefore asked whether there are changes in the mitochondria of $b c l-w^{-/-}$ neurons that might explain the observed axonal degeneration. Because mitochondrial morphology is very dynamic and can influence mitochondrial function, transport, and health, we first examined axonal mitochondrial morphology in $b c l-w^{+/+}$and $b c l-w^{-/-}$DRG cultures. Visualization of mitochondria with MitoTracker dye revealed that axonal mitochondria from $b c l-w^{-1-}$ DRG neurons are significantly longer than axonal mitochondria from $b c l-w^{+/+}$DRG neurons $\left(b c l-w^{+/+}, 0.541 \pm 0.006 \mu \mathrm{m} ; b c l-\right.$ $w^{-/-}, 0.636 \pm 0.008 \mu \mathrm{m} ; p<0.001$ ) (Fig. $7 A, B$ ). The distribution of mitochondria within axons is similar for $b c l-w^{+/+}$and $b c l-w^{-1-}$ DRG neurons, indicating that mitochondria are localized properly within $b c l-w^{-/-}$axons (Fig. 7C).
Mitochondria undergo fission and fusion to repair themselves, exchange DNA, and adjust to changing environmental conditions (for review, see Detmer and Chan, 2007; Tatsuta and Langer, 2008). Alterations in the relative amounts of fission and fusion can result in elongated or shortened mitochondria. We therefore examined whether proteins regulating mitochondrial fission and fusion are altered in $b c l-w^{-/-}$DRG neurons. Total mitochondrial content, as assessed by VDAC protein levels normalized to total cellular protein or to cellular actin, is unchanged in $b c l-w^{-/-}$DRG neurons (Fig. 7E). Protein levels of DRP1 and FIS1, which regulate fission, as well as MFN2 and OPA1, which regulate fusion, are unaltered in $b c l-w^{-1-}$ mice, suggesting that increased mitochondrial length in $b c l-w^{-/-}$sensory neuron axons does not result from changes in expression of these fission and fusion proteins (Fig. 7E).

Mitochondrial membrane potential $\left(\Delta \psi_{\mathrm{m}}\right)$ is another characteristic linked to mitochondrial function and health. Measurements of $\Delta \psi_{\mathrm{m}}$ by staining with the voltage-sensitive mitochondrial dye TMRE demonstrate that axonal mitochondria from $b c l-w^{-1-}$ DRG neurons have a significantly increased $\Delta \psi_{\mathrm{m}}$ compared with $b c l$ $w^{+/+}$DRG neurons (Fig. 7D). Intriguingly, mitochondria within cell bodies of $b c l-w^{-/-}$ DRG neurons show no difference in $\Delta \psi_{\mathrm{m}}$ compared with $b c l-w^{+/+}$DRG neurons. These results demonstrate that axonal mitochondria from $b c l-w^{-/-}$ DRG neurons have abnormal $\Delta \psi_{\mathrm{m}}$, reflecting localized impaired mitochondrial function that may contribute to the selective axonal degeneration seen in vivo and in vitro.

Because one major role of the mitochondria is to provide energy for the cell in the form of ATP, we asked whether there are any changes in the ATP level of $b c l-w^{-1-}$ DRG neurons. Using a luciferase-based assay to measure cellular ATP, we find that ATP levels in cultured DRG neurons from $b c l-w^{-/-}$mice are reduced compared with $b c l-w^{+/+}$mice $\left(69.5 \pm 10 \%\right.$ of $b c l-w^{+/+}$levels; $n=$ $5, p<0.01$ by $z$ test). The reduced level of ATP in $b c l-w^{-/-}$DRG neurons indicates that these neurons are energetically compromised. Together, these results identify mitochondrial abnormalities in $b c l-w^{-l-}$ DRG neurons that preferentially affect the mitochondria within axons. These abnormalities, independently or in combination, cause sensory neuron axonal degeneration in $b c l-w^{-/-}$mice.

\section{Discussion}

Small fiber sensory neuropathy is a neurodegenerative disorder in which there is loss of nociceptive innervation, decreased sensitivity to thermal stimuli, and painful paresthesias. Efforts at discovering an effective treatment have been hindered by a lack of animal models. In the studies reported here, we demonstrate that the anti-apoptotic protein $\mathrm{Bcl}-\mathrm{w}$ is critical for maintaining axonal integrity in sensory neurons, and thus $b c l-w^{-/-}$mice provide a model for this disease. Between young adulthood (2-3 months) and middle age (4-8 months), $b c l-w^{-/-}$mice develop impaired nociceptive responses to thermal sensation. The anatomic corre- 
A
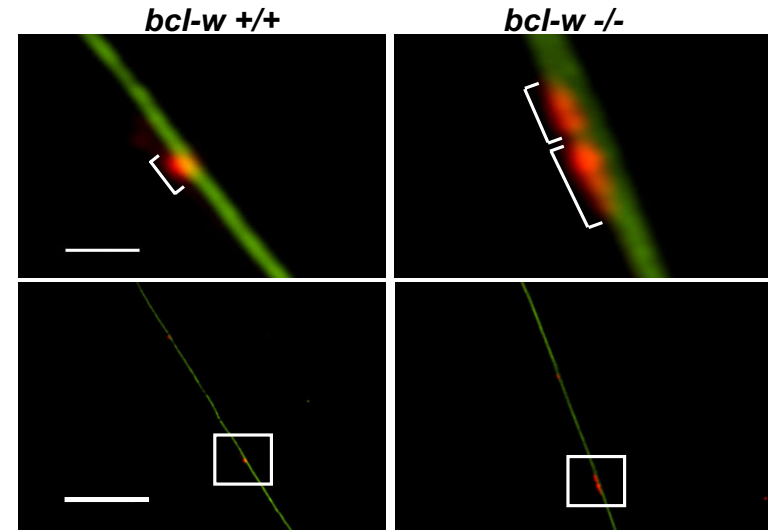

B

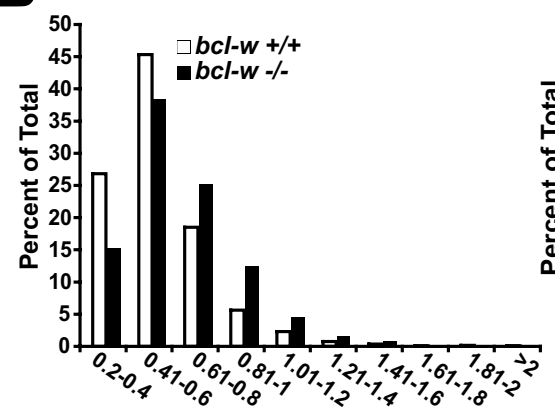

Mitochondrial length (um)

C

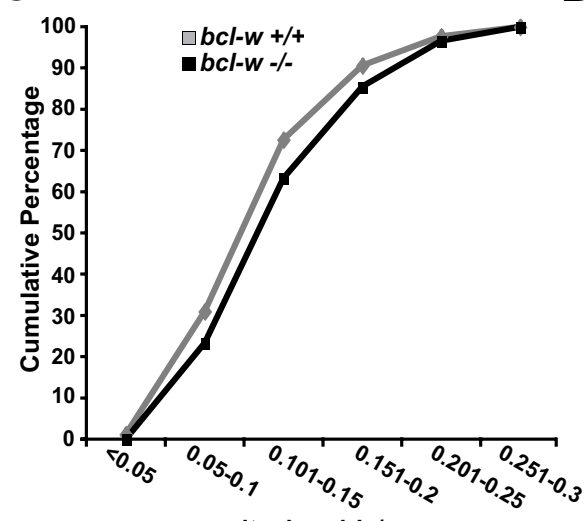

mitochondria/um
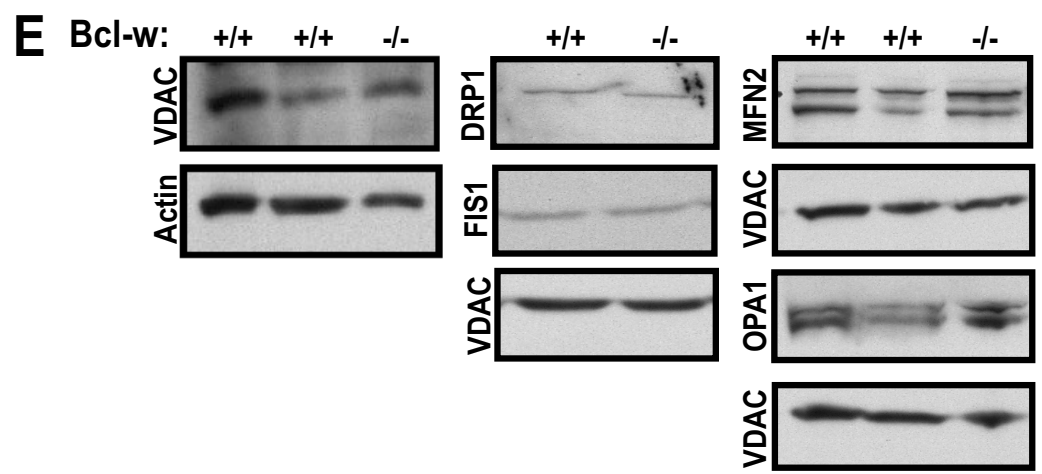

Figure 7. Mitochondria from $b c l-w^{-/-}$DRGs have abnormal morphology and impaired function. $A$, Representative images of mitochondria stained with MitoTracker dye in Tuj1-labeled axons of cultured DRG neurons. Scale bars: top, $1 \mu \mathrm{m} ;$ bottom, $10 \mu \mathrm{m}$. Mitochondrial length in DRG axons from $b c l-w^{-1-}$ mice is increased compared with $b c l-w^{+/+}\left(^{*} p<0.001 ; n=1350\right.$ mitochondria from $5 \mathrm{bcl}-w^{+/+}$animals; $n=1198$ mitochondria from $6 \mathrm{bcl}-w^{-/-}$animals). $\boldsymbol{B}$, Distribution plots of mitochondrial sizes show that the population of mitochondria in $b \mathrm{Cl}_{-} w^{-/-}$DRG axons is shifted toward longer lengths. C, Cumulative percentage plot late of this progressive neuropathy is a loss of epidermal innervation, without loss of sensory neuron cell bodies. Because Bcl-w is predominantly localized to mitochondria, we investigated changes in mitochondrial function that might contribute to axonal degeneration. We find that axonal mitochondria are elongated and axonal mitochondrial membrane potential is increased. Additionally, cellular ATP levels in $b c l-w^{-1-}$ DRGs are reduced. Thus, the progressive axonal loss in $b c l$ $w^{-1-}$ mice is likely to reflect impaired mitochondrial function and alterations in cellular energy levels.

The balance between cell proliferation and cell death is crucial in all tissues, particularly in the nervous system, in which there is limited capacity to generate new cells. Because the Bcl-2 family of proteins regulate apoptosis, expression of the various proapoptotic and anti-apoptotic family members determine responses to a variety of apoptotic stimuli (for review, see Adams and Cory, 1998; Cory and Adams, 2002; Danial and Korsmeyer, 2004). $\mathrm{Bcl}-\mathrm{w}$, an anti-apoptotic member of the Bcl-2 family, is expressed in several tissues, with particularly high levels of Bcl-w in the adult nervous system (Hamnér et al., 1999; O’Reilly et al., 2001). However, initial reports on $b c l-w^{-1-}$ mice reported that Bcl-w is necessary for spermatogenesis but is not required in other tissues (Print et al., 1998; Ross et al., 1998). Additional analysis revealed a role for $\mathrm{Bcl}-\mathrm{w}$ in mediating survival responses to diverse damaging stimuli. Mice lacking Bcl-w show increased apoptosis in the intestine in response to $\gamma$-irradiation or cytotoxic treatment (Pritchard et al., 2000) and decreased intestinal adaptation after small bowel resection (Bernal et al., 2006). In the nervous system, Bcl-w is upregulated after ischemic stroke (Minami et al., 2000;

\footnotetext{
of mitochondria distribution shows there is no difference in axonal mitochondria distributions in $b \mathrm{Cl}^{-w^{+/+}}$and $b \mathrm{cl}-$ $w^{-/-}$DRG neurons $(p>0.05$ by Kolmogorov-Smirnov test; $n=82$ axons from 2 bcl- $w^{+/+}$animals $; n=89$ axons from 2 $b\left(1-w^{-/-}\right.$animals). $\boldsymbol{D}$, Measurements of fluorescence intensity of the voltage-sensitive dye TMRE demonstrates increased membrane potential in axonal mitochondria of $b \mathrm{Cl}_{-} w^{-1-}$ DRG neurons $\left({ }^{*} p<0.001 ; n=609\right.$ cell body mitochondria and 822 axonal mitochondria from $2 \mathrm{bcl}-w^{+/+}$animals; $n=$ 1688 cell body mitochondria and 1608 axonal mitochondria from $3 \mathrm{bcl}-w^{-1-}$ animals). $\boldsymbol{E}$, Mitochondrial fission and fusion proteins are expressed at normal levels in $b \mathrm{Cl}_{-} w^{-/-}$DRGs. Immunoblotting of mitochondrial proteins in $b \mathrm{Cl}_{-} \mathrm{w}^{+/+}$and $b c 1-w^{-1-}$ DRGs shows no change in the levels of VDAC, MFN2, OPA1, DRP1, or FIS1. Loading control for VDAC levels is actin; VDAC is used as loading control for mitochondrial content for other proteins $(n=3)$.
} 
Yan et al., 2000) and focally evoked seizure (Henshall et al., 2001) and protects against amyloid $\beta$-induced toxicity (Yao et al., 2005). Here we show that a lack of $\mathrm{Bcl}-\mathrm{w}$ results in age-related dying back of axons innervating all layers of the epidermis and decreased sensitivity to noxious thermal stimuli. Thus, we propose that Bcl-w protects against axonal degeneration associated with aging.

Neurodegenerative diseases can present primarily as axonopathies without coincident cell body loss. However, there is conflicting evidence regarding whether or not axonal apoptosis represents a process distinct from classical cellular apoptosis. In the progressive motor neuropathy ( $p m n / p m n$ ) mouse model of motor neuron disease, overexpression of a Bcl-2 transgene protects motor neuron cell bodies from undergoing apoptosis but has no effect on distal axonopathy or disease progression (Sagot et al., 1995). Bcl-2 overexpression also rescues retinal ganglion cell bodies from undergoing apoptosis after axotomy, but axonal degeneration still occurs (Burne et al., 1996). Initial studies suggested that activated caspases are not observed in axons undergoing degeneration after axotomy or neurotrophin deprivation and that caspase inhibitors do not delay axonal degeneration in these cases (Finn et al., 2000).

However, there is evidence that apoptotic machinery does in fact play a role in axonal degeneration. Neurites undergoing degeneration show many characteristics of apoptosis, including membrane blebbing, exposure of phosphatidylserine on the extracellular face of the membrane, and loss of mitochondrial membrane potential (Ivins et al., 1998; Mattson et al., 1998; Sievers et al., 2003). Furthermore, this process can be caspase dependent, because activated caspase 3 or activated caspase 6 are detected in degenerating axons, and axonal degeneration can be blocked with caspase inhibitors (Ivins et al., 1998; Mattson et al., 1998; Nikolaev et al., 2009). Together, a picture of axonal apoptosis is emerging in which death of axons is controlled by molecular regulators that overlap with, but are not identical to, those that regulate cell body death. Here we show that Bcl-w is expressed at high levels in sensory neuron axons, and lack of Bcl-w results in a distinct pattern of axonal degeneration without cell body loss. These data suggest a particular role for Bcl-w in axonal viability. Additional work will need to address whether Bcl-w also prevents dying back of axons in other neuronal populations.

$\mathrm{Bcl}-\mathrm{w}$ is predominantly localized to mitochondria, in which it can interact with other members of the Bcl-2 family and promote survival (O'Reilly et al., 2001) (for review, Adams and Cory, 1998; Cory and Adams, 2002; Danial and Korsmeyer, 2004). Here, we identify several mitochondrial abnormalities that occur in the absence of Bcl-w. First, axonal mitochondria are longer in $\mathrm{bcl}$ $w^{-/-}$than in $b c l-w^{+/+}$DRG neurons (Fig. 7A,B). Similarly, it has been reported previously that mitochondria in Purkinje cell dendrites of $b c l-w^{-1-}$ mice are elongated (Liu and Shio, 2008). Lack of Bcl-w does not alter expression of proteins critical for mitochondrial fission and fusion (Fig. 7E), suggesting that Bcl-w may alter mitochondrial length by direct interactions with components of the fission/fusion machinery, as reported for other Bcl-2 family members (Delivani et al., 2006; Karbowski et al., 2006; Brooks et al., 2007; Berman et al., 2009). A second abnormality in axonal mitochondria from $b c l-w^{-1-}$ sensory neurons is increased mitochondrial potential, $\Delta \psi_{\mathrm{m}}$ (Fig. 7D). Although the relationship between $\Delta \psi_{\mathrm{m}}$ and mitochondrial function is complex, studies in Caenorhabditis elegans and mouse neurons have demonstrated that lower $\Delta \psi_{\mathrm{m}}$ can be protective and extend lifespan, whereas higher $\Delta \psi_{\mathrm{m}}$ can lead to neurodegeneration (Lemire et al., 2009; Abramov et al., 2010). Thus, increased $\Delta \psi_{\mathrm{m}}$ in axonal mitochondria of $b c l-w^{-1-}$ sensory neurons may contribute to the observed axonal degeneration. Furthermore, cellular ATP levels are reduced in $b c l-w^{-1-}$ neurons, which is likely to be detrimental for cellular survival and function. This is particularly true in energetically demanding neurons in which mitochondria provide localized energy sources at synapses, axonal branch points, and nodes of Ranvier (for review, see Hollenbeck and Saxton, 2005). Together, the mitochondrial abnormalities in $b c l-w^{-/-}$sensory neurons are likely to contribute to the observed axonal degeneration.

The studies presented here, in combination with previously published studies, reveal a role for Bcl-w in DRG sensory neurons throughout life. Previously, we demonstrated that DRGs from $b c l-w^{-/-}$mice at E14 and postnatal day 0 (P0) show evidence of increased apoptosis compared with $b c l-w^{+/+}$animals (PazyraMurphy et al., 2009). Here, we demonstrate that Bcl-w plays an important role in axonal maintenance of adult nociceptor neurons, because $b c l-w^{-1-}$ mice display reduced epidermal innervation without significant soma loss. Thus, a puzzling question remains: how can the increase in apoptosis observed in young (E14 to P0) $b c l-w^{-/-}$animals be reconciled with normal numbers of cell bodies in adult DRGs? One possibility may be that the observed increase in apoptosis in young animals is a result of a prolonged apoptotic process in $b c l-w^{-/-}$mice. Because apoptosis requires ATP for activation of the apoptosome (Kim et al., 2005; Riedl et al., 2005), reduced ATP levels in $b c l-w^{-/-}$neurons might slow the apoptotic cascade. Thus, the length of time any cell is labeled "apoptotic" would be increased, without any actual increases in the number of cells undergoing apoptosis. An alternative possibility is that levels of proliferation and apoptosis in young $b c l-w^{-/-}$animals might both be increased, so that there are more cells in DRGs in young $b c l-w^{-/-}$mice. In support of this possibility, Bcl-w has been shown to have anti-proliferative effects in some studies (O’Reilly et al., 1996; Huang et al., 1997; Yan et al., 2003). An increase in proliferation, combined with increased apoptosis, could result in equivalent numbers of DRG neurons at older ages. Finally, another possibility is that increased apoptosis of DRG cells early in development reflects increased apoptosis of glia rather than of neurons. The markers of apoptosis used for the early DRG (terminal deoxynucleotidyl transferasemediated biotinylated UTP nick end labeling, condensed nuclei) are not specific to neurons and would also mark satellite glial cells undergoing apoptosis. In contrast, the neuron specific marker Tuj1 was used to count neurons in adult DRGs.

In conclusion, the studies presented here demonstrate a specialized role for the anti-apoptotic protein Bcl-w in the maintenance of adult sensory neurons. In $b c l-w^{-1-}$ mice, we observe a progressive decline in thermal sensitivity, concomitant with a loss of small fiber nociceptor innervation of the epidermis. Intriguingly, this pathology seems localized to the axons, because neuronal cell bodies in the dorsal root ganglia are not lost. Our data indicate that axonal dying back results, either directly or indirectly, from abnormal mitochondrial function, including decreased ATP levels, increased membrane potential in axonal mitochondria, and elongation of axonal mitochondria. $\mathrm{Bcl}-\mathrm{w}^{-1-}$ mice demonstrate a striking resemblance to patients with small fiber sensory neuropathy and so provide a novel model to investigate the pathology and potential treatment of this human disorder.

\section{References}

Abramov AY, Smulders-Srinivasan TK, Kirby DM, Acin-Perez R, Enriquez JA, Lightowlers RN, Duchen MR, Turnbull DM (2010) Mechanism of neurodegeneration of neurons with mitochondrial DNA mutations. Brain 133:797-807.

Adams JM, Cory S (1998) The Bcl-2 protein family: arbiters of cell survival. Science 281:1322-1326.

Berman SB, Chen YB, Qi B, McCaffery JM, Rucker EB 3rd, Goebbels S, Nave 
KA, Arnold BA, Jonas EA, Pineda FJ, Hardwick JM (2009) Bcl-xL increases mitochondrial fission, fusion, and biomass in neurons. J Cell Biol 184:707-719.

Bernal NP, Stehr W, Coyle R, Erwin CR, Warner BW (2006) Epidermal growth factor receptor signaling regulates bax and bcl-w expression and apoptotic responses during intestinal adaptation in mice. Gastroenterology 130:412-423.

Brooks C, Wei Q, Feng L, Dong G, Tao Y, Mei L, Xie ZJ, Dong Z (2007) Bak regulates mitochondrial morphology and pathology during apoptosis by interacting with mitofusins. Proc Natl Acad Sci U S A 104:11649-11654.

Burne JF, Staple JK, Raff MC (1996) Glial cells are increased proportionally in transgenic optic nerves with increased number of axons. J Neurosci 16:2064-2073.

Campenot RB (1982) Development of sympathetic neurons in compartmentalized cultures. II. Local control of neurite survival by nerve growth factor. Dev Biol 93:13-21.

Chen CL, Broom DC, Liu Y, de Nooij JC, Li Z, Cen C, Samad OA, Jessell TM, Woolf CJ, Ma Q (2006) Runxl determines nociceptive sensory neuron phenotype and is required for thermal and neuropathic pain. Neuron 49:365-377.

Cory S, Adams JM (2002) The Bcl2 family: regulators of the cellular life-ordeath switch. Nat Rev Cancer 2:647-656.

Danial NN, Korsmeyer SJ (2004) Cell death: critical control points. Cell 116:205-219.

Deckwerth TL, Johnson EM Jr (1994) Neurites can remain viable after destruction of the neuronal soma by programmed cell death (apoptosis). Dev Biol 165:63-72.

Delivani P, Adrain C, Taylor RC, Duriez PJ, Martin SJ (2006) Role for CED-9 and Egl-1 as regulators of mitochondrial fission and fusion dynamics. Mol Cell 21:761-773.

Detmer SA, Chan DC (2007) Functions and dysfunctions of mitochondrial dynamics. Nat Rev Mol Cell Biol 8:870-879.

Ernsberger U (2009) Role of neurotrophin signaling in the differentiation of neurons from dorsal root ganglia and sympathetic ganglia. Cell Tissue Res 336:349-384.

Finn JT, Weil M, Archer F, Siman R, Srinivasan A, Raff MC (2000) Evidence that Wallerian degeneration and localized axon degeneration induced by local neurotrophin deprivation do not involve caspases. J Neurosci 20:1333-1341.

Hamnér S, Skoglösa Y, Lindholm D (1999) Differential expression of bcl-w and bcl-x messenger RNA in the developing and adult rat nervous system. Neuroscience 91:673-684

Hart AM, Terenghi G (2004) Frozen-section fluorescence microscopy and stereology in the quantification of neuronal death within dorsal root ganglia. J Mol Histol 35:565-580.

Henshall DC, Skradski SL, Lan JQ, Ren T, Simon RP (2001) Increased Bcl-w expression following focally evoked limbic seizures in the rat. Neurosci Lett 305:153-156.

Heerssen HM, Pazyra MF, Segal RA (2004) Dynein motors transport activated Trks to promote survival of target-dependent neurons. Nat Neurosci 7:596-604.

Hollenbeck PJ, Saxton WM (2005) The axonal transport of mitochondria. J Cell Sci 118:5411-5419.

Huang DC, O’Reilly LA, Strasser A, Cory S (1997) The anti-apoptosis function of Bcl-2 can be genetically separated from its inhibitory effect on cell cycle entry. EMBO J 16:4628-4638.

Ivins KJ, Bui ET, Cotman CW (1998) $\beta$-amyloid induces local neurite degeneration in cultured hippocampal neurons: evidence for neuritic apoptosis. Neurobiol Dis 5:365-378.

Karbowski M, Norris KL, Cleland MM, Jeong SY, Youle RJ (2006) Role of Bax and Bak in mitochondrial morphogenesis. Nature 443:658-662.

Kim HE, Du F, Fang M, Wang X (2005) Formation of apoptosome is initiated by cytochrome c-induced dATP dydrolysis and subsequent nucleotide exchange on Apaf-1. Proc Natl Acad Sci U S A 102:17545-17550.

Lacomis D (2002) Small-fiber neuropathy. Muscle Nerve 26:173-188.

Lemire BD, Behrendt M, DeCorby A, Gásková D (2009) C. elegans longevity pathways converge to decrease mitochondrial membrane potential. Mech Ageing Dev 130:461-465.

Liu QA, Shio H (2008) Mitochondrial morphogenesis, dendrite development, and synapse formation in cerebellum require both $\mathrm{Bcl}-\mathrm{w}$ and the glutamate receptor $\delta 2$. PLoS Genet 4:e1000097.
Mattson MP, Keller JN, Begley JG (1998) Evidence for synaptic apoptosis. Exp Neurol 153:35-48.

Minami M, Jin KL, Li W, Nagayama T, Henshall DC, Simon RP (2000) $\mathrm{Bcl}-\mathrm{w}$ expression is increased in brain regions affected by focal cerebral ischemia in the rat. Neurosci Lett 279:193-195.

Nikolaev A, McLaughlin T, O'Leary DD, Tessier-Lavigne M (2009) APP binds DR6 to trigger axon pruning and neuron death via distinct caspases. Nature 457:981-989.

O'Reilly LA, Huang DC, Strasser A (1996) The cell death inhibitor Bcl-2 and its homologues influence control of cell cycle entry. EMBO J 15:6979-6990.

O’Reilly LA, Print C, Hausmann G, Moriishi K, Cory S, Huang DC, Strasser A (2001) Tissue expression and subcellular localization of the pro-survival molecule Bcl- w. Cell Death Differ 8:486-494.

Pazyra-Murphy MF, Hans A, Courchesne SL, Karch C, Cosker KE, Heerssen HM, Watson FL, Kim T, Greenberg ME, Segal RA (2009) A retrograde neuronal survival response: target-derived neurotrophins regulate MEF2D and bcl-w. J Neurosci 29:6700-6709.

Periquet MI, Novak V, Collins MP, Nagaraja HN, Erdem S, Nash SM, Freimer ML, Sahenk Z, Kissel JT, Mendell JR (1999) Painful sensory neuropathy: prosepective evaluation using skin biopsy. Neurology 53:1641-1647.

Print CG, Loveland KL, Gibson L, Meehan T, Stylianou A, Wreford N, de Kretser D, Metcalf D, Köntgen F, Adams JM, Cory S (1998) Apoptosis regulator bcl-w is essential for spermatogenesis but appears otherwise redundant. Proc Natl Acad Sci U S A 95:12424-12431.

Pritchard DM, Print C, O’Reilly L, Adams JM, Potten CS, Hickman JA (2000) Bcl-w is an important determinant of damage-induced apoptosis in epithelia of small and large intestine. Oncogene 19:3955-3959.

Raff MC, Whitmore AV, Finn JT (2002) Axonal self-destruction and neurodegeneration. Science 296:868-871.

Riedl SJ, Li W, Chao Y, Schwarzenbacher R, Shi Y (2005) Structure of the apoptotic protease-activating factor 1 bound to ADP. Nature 434:926-933.

Ross AJ, Waymire KG, Moss JE, Parlow AF, Skinner MK, Russell LD, MacGregor GR (1998) Testicular degeneration in Bclw-deficient mice. Nat Genet 18:251-256.

Sagot Y, Dubois-Dauphin M, Tan SA, de Bilbao F, Aebischer P, Martinou JC, Kato AC (1995) Bcl-w overexpression prevents motoneuron cell body loss but not axonal degeneration in a mouse model of neurodegenerative disease. J Neurosci 15:7727-7733.

Sagot Y, Tan SA, Hammang JP, Aebischer P, Kato AC (1996) GDNF slows loss of motoneurons but not axonal degeneration of premature death of pmn/pmn mice. J Neurosci 16:2335-2341.

Sasaki Y, Vohra BP, Lund FE, Milbrandt J (2009) Nicotinamide mononucleotide adenylyl transferase-mediated axonal protection requires enzymatic activity but not increased levels of neuronal nicotinamide adenine dinucleotide. J Neurosci 29:5525-5535.

Sievers C, Platt N, Perry VH, Coleman MP, Conforti L (2003) Neurites undergoing Wallerian degeneration show an apoptotic-like process with annexin $\mathrm{V}$ positive staining and loss of mitochondrial membrane potential. Neurosci Res 46:161-169.

Stewart JD, Low PA, Fealey RD (1992) Distal small fiber neuropathy: results of tests of sweating and automonic cardiovascular reflexes. Muscle Nerve 15:661-665.

Tatsuta T, Langer T (2008) Quality control of mitochondria: protection against neurodegeneration and ageing. EMBO J 27:306-314.

Vickers JC, King AE, Woodhouse A, Kirkcaldie MT, Staal JA, McCormack GH, Blizzard CA, Musgrove RE, Mitew S, Liu Y, Chuckowree JA, Bibari O, Dickson TC (2009) Axonopathy and cytoskeletal disruption in degenerative diseases of the central nervous system. Brain Res Bull 80:217-223.

Yan C, Chen J, Chen D, Minami M, Pei W, Yin XM, Simon RP (2000) Overexpression of the cell death suppressor Bcl-w in ischemic brain: implications for a neuroprotective role via the mitochondrial pathway. J Cereb Blood Flow Metab 20:620-630.

Yan W, Huang JX, Lax AS, Pelliniemi L, Salminen E, Poutanen M, Toppari J (2003) Overexpression of $\mathrm{Bcl}-\mathrm{w}$ in the testis disrupts spermatogenesis: revelation of a role of BCL-W in male germ cell cycle control. Mol Endocrinol 17:1868-1879.

Yao M, Nguyen TV, Pike CJ (2005) $\beta$-amyloid-induced neuronal apoptosis involves c-Jun N-terminal kinase-dependent downregulation of Bcl-w. Neurobiol Dis 25:1149-1158.

Zylka MJ, Rice FL, Anderson DJ (2005) Topographically distinct epidermal nociceptive circuits revealed by axonal tracers targeted to Mrgprd. Neuron 45:17-25. 